\title{
Utjecaj natrijeva alginata na svojstva poli(etilen-oksidal kao matrice za pripravu čvrstih polimernih elektrolita
}

\author{
S. Perinović Jozić, A. Sesar, Z. Grubač i B. Andričić
}

Sveučilište u Splitu, Kemijsko-tehnološki fakultet, Ruđera Boškovića 35, 21000 Split, Hrvatska

\begin{abstract}
Sažetak
Istraživan je utjecaj natrijeva alginata (NaAlg) na strukturu i svojstva filmova poli(etilen-oksida) (PEO) izlivenih iz vodenih otopina primjenom infracrvene spektroskopije s Fourierovom transformacijom (FT-IR), diferencijalne pretražne kalorimetrije (DSC), neizotermne termogravimetrije (TG) i elektrokemijske impedancijske spektroskopije (EIS). Cilj istraživanja je pronalaženje optimalne mješavine za pripravu filma čvrstog polimernog elektrolita (SPE) za litij-ionske baterije (LIB). U filmovima mješavina PEO/NaAlg stvaraju se vodikove veze između PEO-a i NaAlg-a te nastaju mješljive mješavine s manjim udjelom kristalne faze u odnosu na film čistog PEO-a. Filmovi mješavina toplinski su nestabilniji od filma čistog PEO-a i pokazuju dielektrična svojstva. Zbog najmanjeg udjela kristalne faze PEO-a mješavina 80PEO/20NaAlg može biti polimerna matrica koja bi dodatkom litijeve soli tvorila pogodan SPE.
\end{abstract}

Ključne riječi

Poli(etilen-oksid), natrijev alginat, vodikova veza, kristalnost, toplinska postojanost, impedancija

\section{Uvod}

Iscrpljivanje neobnovljivih fosilnih izvora te svakodnevni porast problema vezanih za očuvanje okoliša usmjerilo je čovječanstvo na uporabu alternativnih izvora energije u različite namjene, na prvom mjestu u automobilskoj industriji (električna vozila), gorivim člancima, prijenosnim elektronskim uređajima i za skladištenje energije iz električne mreže. ${ }^{1-4}$ Litij-ionske baterije (LIB) s elektrolitom u čvrstom stanju smatraju se najboljom opcijom sustava za skladištenje energije zbog visoke razine sigurnosti, pouzdanosti, dugog vijeka trajanja i niskih troškova. ${ }^{1,3} \mathrm{U}$ tom smislu poboljšanje svojstava čvrstih polimernih elektrolita (SPE) jedan je od najvećih izazova. SPE se uglavnom sastoje od polimerne matrice i soli alkalijskog metala, a prednosti im se očituju u nemogućnosti curenja elektrolita, maloj zapaljivosti, maloj masi, dobroj savitljivosti, preradljivosti, sigurnosti i stabilnosti kontakta s elektrodama, čime se ispunjavaju zahtjevi u primjeni LIB-a. ${ }^{1-4}$ Osim navedenog, SPE trebaju ispuniti i zahtjeve za dobrom toplinskom postojanosti, velikom ionskom provodnosti pri sobnoj temperaturi i širokim područjem elektrokemijske stabilnosti. ${ }^{1,2}$ Velika prednost SPE-a kod LIB-a je i njihova dvostruka funkcionalnost u vidu elektrolita i separatora elektroda. ${ }^{2}$ Do danas je razvijen je čitav niz SPE-a na bazi poli(etilen-oksida) (PEO), polikarbonata (PC) i polisiloksana, pri čemu se dosta pažnje posvetilo proučavanju rasta Li-dendrita, tj. sprječavanju rasta. ${ }^{1,2,4}$ Od spomenutih polimernih matrica SPE-a najčešće se istraživao PEO kao polimer koji je pokazao najviše potencijala za tu namjenu. ${ }^{1-3}$ Glavni razlog uporabe PEO-a je u velikoj moći otapanja ionskih soli, tj. polimerni lanci djeluju kao otapalo soli koja disocira. ${ }^{3,4}$ PEO je polimer koji pokazuje veliku sklonost stvaranju kristalne faze, a prijenos kationa povezan je s gibanjem segmenata polimernog lan-

*Autor za dopisivanje: doc. dr. sc. Sanja Perinović Jozić e-pošta: sanja@ktf-split.hr ca. ${ }^{1-3}$ Kako su polimerni lanci fleksibilniji u amorfnoj fazi, velika ionska provodnost povezana je s amorfnom fazom polimernog elektrolita. Također, uočena je povezanost između smanjivanja prijenosa iona uslijed gibanja segmenata glavnog polimernog lanca zbog snižavanja temperature i povećavanja kristalnosti. ${ }^{1,2}$ Zbog svega navedenog, nastoji se spriječiti stvaranje kristalne faze PEO-a da bi se omogućilo neometano gibanje segmenata polimernog lanca. ${ }^{1}$ Općenito je poznato da se kontinuirano gibanje segmenata lanca amorfne faze nužno za transport iona odvija iznad staklišta. ${ }^{1,2}$ Idealni SPE-i trebali bi imati nisko staklište, kako bi se pri sobnoj temperaturi nalazili u gumastom stanju što bi omogućilo provodnost sličnu kapljevitim elektrolitima. 1,2,4 Poboljšanje provodnosti SPE-a temelji se na razvoju novih amorfnih polimera ili kopolimera, pripravi amorfnih polimernih mješavina itd. ${ }^{1}$ Priprava čvrstih elektrolita na bazi polimernih mješavina zasniva se na sprječavanju pravilnog slaganja molekulnih lanaca osnovne polimerne matrice, pri čemu nastaje manji udio kristalne faze. Mješljivost ili djelomična mješljivost značila bi ujedno i bolja mehanička svojstva materijala koja se kod SPE-a primarno odnose na dobru savitljivost materijala. ${ }^{1}$ Prednosti mješljivosti PEO-a i visokorazgranatog poli[bis(trietilen-glikol)benzoata] s krajnjim acetilnim skupinama kao SPE potvrdili su Z. Wen i sur., ${ }^{5}$ jer se uslijed mješljivosti smanjio udio kristalne faze PEO-a te povećala ionska provodnost i elektrokemijska stabilnost. M. S. Bostan $i$ sur. ${ }^{6}$ također su utvrdili mješljivost trokomponente mješavine kitozan/PEO/ levan, koja je dovela do smanjivanja udjela kristalne faze, poboljšanja toplinskih i mehaničkih svojstava mješavine. Djelomičnu mješljivost utvrdili su $P$. Dhatarwal i sur. ${ }^{3}$ kod mješavina PEO-a i poli(metil-metakrilata) uz dodatak litijeve soli, pri čemu se dobila amorfna mješavina dobre ionske provodnosti i elektrokemijske stabilnosti. Mješljivost PEO-a i poli(akril-amida) dovela je do znatnog smanjivanja udjela kristalne faze PEO-a u mješavini te poboljšanja toplinske stabilnosti i mehaničkih svojstava. ${ }^{7}$ 
Alginati su amonijeve i metalne soli alginske kiseline koja pripada skupini prirodnih polisaharaida a dobiva se iz različitih velikih smeđih morskih algi. ${ }^{8-10}$ Soli jednovalentnih kationa kao što je natrijev alginat (NaAlg) lako se otapaju u vodi, dok su soli dvovalentnih kationa u njoj netopljive. ${ }^{8,9}$ Alginati imaju široku primjenu u kozmetici, medicini, farmaceutskoj industriji, biotehnologiji, prehrambenoj industriji itd. ${ }^{8-10} \mathrm{NaAlg}$ ima svojstva polielektrolita. ${ }^{8,10}$ Zbog navedenog, zanimljiv je za ispitivanje uporabe kao modifikatora SPE-a kod LIB-a. Cilj njegova dodatka bio bi, u slučaju PEO-a, sprječavanje kristalizacije kako bi se poboljšala električna provodnost SPE-a.

Priprava polimernih filmova podrazumijeva različite tehnike priprave, a jedna od njih je izlijevanje filmova iz polimernih otopina. Kod priprave SPE-a otapalo mora otopiti polimer ili polimere ako se pripravlja mješavina, ali i sol alkalijskog metala. Izrada filmova PEO-a izlijevanjem iz vodenih otopina ekološki je prihvatljivija a, kako je NaAlg također topljiv u vodi, moguća je priprava filmova njihovih mješavina.

U ovom radu provedeno je istraživanje utjecaja različitih udjela NaAlg-a na smanjenje udjela kristalne faze u filmovima pripravljenim od PEO-a. Serije polimernih mješavina pripravljene su izlijevanjem filmova iz vodenih otopina, pri čemu su se interakcije između polimera proučavale uporabom infracrvene spektroskopije s Fourierovom transformacijom (FT-IR). Ispitivanje smanjenja udjela kristalne faze PEO-a provelo se pomoću diferencijalne pretražne kalorimetrije (DSC). Toplinska postojanost mješavina određena je termogravimetrijski u neizotermnim uvjetima (TG), dok je elektrokemijska impedancijska spektroskopija upotrijebljena za ispitivanje dielektričnih svojstava pripravljenih filmova.

\section{Eksperimentalni dio}

\subsection{Materijali}

Za pripravu PEO/NaAlg mješavina upotrijebljen je praškasti poli(etilen-oksid) (PEO), Sigma-Aldrich, SAD, $\overline{M_{v}}=100000 \mathrm{~g} \mathrm{~mol}^{-1}$, praškasti natrijev alginat (NaAlg) $M^{v}=10000-600000 \mathrm{~g} \mathrm{~mol}^{-1}$, PanReac AppliChem ITW Reagents, Njemačka, i destilirana voda. Praškasti NaAlg se prije priprave filmova sušio pri $100{ }^{\circ} \mathrm{C}$ do konstante mase zbog uobičajeno prisutne vlage.

\subsection{Priprava filmova}

Za pripravu filmova polimernih mješavina sastava prikazanih u tablici 1 upotrijebljene su vodene otopine pojedinog polimera koncentracije $1 \% \mathrm{w} / \mathrm{v}$. Binarne otopine polimera pripremljene su miješanjem odgovarajućih volumena pojedinih polimernih vodenih otopina. Početne polimerne otopine pojedinog polimera miješane su na magnetskoj miješalici $1 \mathrm{~h}$ pri brzini okretaja $400 \mathrm{o} \mathrm{min}^{-1}$, a binarne otopine 1 dan prije izlijevanja u Petrijeve zdjelice. Uklanjanje otapala provodilo se u sušioniku jedan dan pri atmos- ferskom tlaku i pri $25^{\circ} \mathrm{C}$, drugi dan pri $30{ }^{\circ} \mathrm{C}$, a treći dan su zdjelice prebačene u vakuumski sušionik pri $40{ }^{\circ} \mathrm{C}$ (više temperature dovodile su do taljenja) i tlaku od -0,1 MPa te sušene $72 \mathrm{~h}$. Primjeri pripravljenih filmova PEO/NaAlg mješavina prikazani su na slici 1 .

Tablica 1 - Sastav PEO/NaAlg mješavina

Table 1 - Composition of PEO/NaAlg blends

\begin{tabular}{c|c|c}
\hline \multirow{2}{*}{$\begin{array}{c}\text { Uzorak } \\
\text { Sample }\end{array}$} & \multicolumn{2}{|c}{$\begin{array}{c}\text { Sastav mješavine } \\
\text { Blend composition }\end{array}$} \\
\cline { 2 - 3 } & PEO/mas. \% & NaAlg/mas. \% \\
\hline 100PEO/0NaAlg & 100 & 0 \\
\hline 95PEO/5NaAlg & 95 & 5 \\
\hline 90PEO/10NaAlg & 90 & 10 \\
\hline 85PEO/15NaAlg & 85 & 15 \\
\hline 80PEO/20NaAlg & 80 & 20 \\
\hline 75PEO/25NaAlg & 75 & 25 \\
\hline 70PEO/30NaAlg & 70 & 30 \\
\hline 65PEO/35NaAlg & 65 & 35 \\
\hline
\end{tabular}

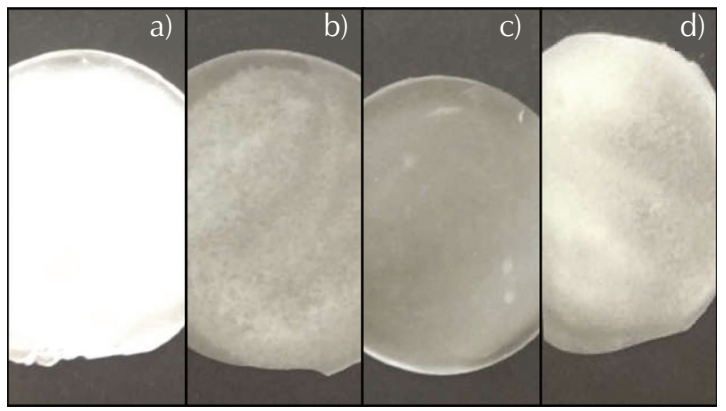

Slika 1 - Primjeri filmova PEO/NaAlg mješavina: a) $100 \mathrm{PEO} / 0 \mathrm{NaAlg}$, b) $90 \mathrm{PEO} / 10 \mathrm{NaAlg}$, c) $80 \mathrm{PEO} / 20 \mathrm{NaAlg}$ i d) $70 \mathrm{PEO} / 30 \mathrm{NaAlg}$

Fig. 1 - Examples of PEO/NaAlg blend films: a) $100 \mathrm{PEO} / 0 \mathrm{NaAlg}$, b) $90 \mathrm{PEO} / 10 \mathrm{NaAlg}$, c) $80 \mathrm{PEO} / 20 \mathrm{NaAlg}$, and d) $70 \mathrm{PEO} / 30 \mathrm{NaAlg}$

\subsection{Infracrvena spektroskopija s Fourierovom transformacijom}

Za određivanje međumolekulnih interakcija s naglaskom na vodikovoj vezi između PEO-a i NaAlg-a upotrijebljen je infracrveni spektrometar s Fourierovom transformacijom (FT-IR) Spectrum One (Perkin-Elmer, SAD). FT-IR spektri $\mathrm{PEO}$ i NaAlg prahova te filmova PEO/NaAlg mješavina snimljeni su tehnikom horizontalne prigušene totalne refleksije (engl. Horizontal Attenuated Total Reflectance, HATR) na cink selenidnom (ZnSe) refleksijskom elementu u području valnih brojeva $(\bar{v})$ od 4000 do $650 \mathrm{~cm}^{-1}$ uz rezoluciju $4 \mathrm{~cm}^{-1}$. 


\subsection{Diferencijalna pretražna kalorimetrija}

Za analizu toplinskih svojstava PEO i NaAlg prahova te pripravljenih filmova $\mathrm{PEO} / \mathrm{NaAlg}$ mješavina upotrijebljen je diferencijalni pretražni kalorimetar (DSC 823e, Mettler Toledo, Švicarska) opremljen sustavom za hlađenje ispod sobne temperature. Instrument je kalibriran indijem $\left(T_{\mathrm{m}}=156,6^{\circ} \mathrm{C}, \Delta H_{\mathrm{m}}=28,45 \mathrm{Jg}^{-1}\right)$. Prije početka rada sustav je stabiliziran od 0,5 do $1 \mathrm{~h}$. Mjerenja su provedena u zatvorenim aluminijskim posudicama probušenih poklopaca u atmosferi dušika $\left(30 \mathrm{~cm}^{3} \mathrm{~min}^{-1}\right)$. Masa ispitaka filmova mješavina bila je oko $10 \mathrm{mg}$. Ispitci su sa sobne temperature najprije ohlađeni na $-90{ }^{\circ} \mathrm{C}$ brzinom $20{ }^{\circ} \mathrm{C} \mathrm{min}{ }^{-1}$ (prvo hlađenje), zadržani pri toj temperaturi $10 \mathrm{~min}$ te zagrijani od $-90{ }^{\circ} \mathrm{C}$ do $110{ }^{\circ} \mathrm{C}$ brzinom $20{ }^{\circ} \mathrm{C} \mathrm{min}^{-1}$ (prvo zagrijavanje). Pri $110^{\circ} \mathrm{C}$ zadržani su $5 \mathrm{~min}$, nakon čega su ponovno ohlađeni na $-90{ }^{\circ} \mathrm{C}$ brzinom $20{ }^{\circ} \mathrm{C} \mathrm{min}^{-1}$ (drugo hlađenje) i zadržani pri toj temperaturi $10 \mathrm{~min}$. $\mathrm{Od}-90^{\circ} \mathrm{C}$ ponovno su zagrijani na $110{ }^{\circ} \mathrm{C}$ brzinom $20{ }^{\circ} \mathrm{C} \mathrm{min}^{-1}$ (drugo zagrijavanje). Temperatura taljenja $\left(T_{\mathrm{m}}\right)$ i temperatura kristalizacije iz taline $\left(T_{\mathrm{mc}}\right)$ određene su kao ekstrapolirane početne temperature prijelaza (taljenje $\left(T_{\text {eim }}\right)$ ili kristalizacija iz taline $\left.\left(T_{\text {eimc }}\right)\right)$, te temperature u vršku endoterme $\left(T_{\mathrm{pm}}\right)$ ili egzoterme prijelaza $\left(T_{\mathrm{pmc}}\right)$. Iz navedenih prijelaza određene su i pripadajuće topline (toplina taljenja $\left(\Delta H_{\mathrm{m}}\right)$ i toplina kristalizacije iz taline $\left(\Delta H_{\mathrm{mc}}\right)$ ). Temperatura staklastog prijelaza $\left(T_{\mathrm{g}}\right)$ određena je kao ekstrapolirana početna temperatura prijelaza $\left(T_{\text {eig }}\right)$ i temperatura pri kojoj je promjena toplinskog kapaciteta $\left(\Delta c_{\mathrm{p}}\right)$ jednaka polovini njegove maksimalne vrijednosti $\left(T_{\mathrm{mg}}\right)$. Pomoću vrijednosti topline taljenja $\left(\Delta H_{\mathrm{m}}\right)$ PEO-a u pojedinoj mješavini i topline taljenja potpuno kristalnog PEO-a $\left(\Delta H^{0}{ }_{m}\right)$ moguće je izračunati stupanj kristalnosti $\left(X_{c}\right)$ primjenom jedn. (1):

$$
X_{\mathrm{C}} / \%=\frac{\Delta H_{\mathrm{m}}}{\Delta H_{100 \%} \cdot W_{\mathrm{PEO} 1}} \cdot 100,
$$

gdje $\Delta H^{0}{ }_{\mathrm{m}}$ iznosi $188 \mathrm{~J} \mathrm{~g}^{-1}$, a $\mathrm{W}$ predstavlja maseni udjel PEO-a u pojedinoj mješavini. ${ }^{11}$

\subsection{Neizotermna termogravimetrija}

Toplinska razgradnja PEO i NaAlg prahova te filmova PEO/ NaAlg mješavina istraživana je neizotermnom termogravimetrijskom (TG) analizom pomoću termogravimetra Pyris 1 TGA (Perkin-Elmer, SAD). Masa ispitaka bila je oko $10 \mathrm{mg}$. Analiza je provedena u temperaturnom području od 50 do $500{ }^{\circ} \mathrm{C}$ u struji dušika (protok je $20 \mathrm{~cm}^{3} \mathrm{~min}^{-1}$ ) pri brzini zagrijavanja $10{ }^{\circ} \mathrm{C} \mathrm{min}^{-1}$. Iz TG i pripadajućih derivativnih termogravimetrijskih (DTG) krivulja određene su sljedeće značajke: temperatura početka razgradnje $\left(T_{\text {onset }}\right)$, masa ispitka pri temperaturi početka razgradnje $\left(m_{\text {onset }}\right)$, temperatura pri kojoj ispitak izgubi $5 \%$ početne mase $\left(T_{5 \%}\right)$, temperatura pri maksimalnoj brzini razgradnje $\left(T_{\max }\right)$, masa ispitka pri temperaturi maksimalne brzine razgradnje $\left(m_{\max }\right)$, maksimalna brzina razgradnje, $\left((\mathrm{d} m / \mathrm{d} T)_{\max }\right)$, gubitak mase u razgradnom stupnju $(\Delta m)$ i ostatna masa ispitka $\left(m_{\mathrm{f}}\right)$.

\subsection{Elektrokemijska impedancijska spektroskopija}

Impedancijska mjerenja provedena su pomoću potenciostata Solartron Electrochemical Interface SI 1287 spojenog s fazno osjetljivim pojačalom Solartron HF Frequency response analyzer SI 1255. Riječ je o računalom vođenom sustavu, a podatci su analizirani primjenom programa Zplot/Zwiew (Scribner Associates, Inc., SAD). Uzorak polimernog filma stavljen je između dviju elektroda od nehrđajućeg čelika, a bakrenim žicama ostvaren je kontakt s mjernim uređajem. Impedancijska mjerenja provedena su u frekvencijskom području od $1 \mathrm{MHz}$ do $1 \mathrm{~Hz}$ s amplitudom pobude od $\pm 20 \mathrm{mV}$.

\section{Rezultati i rasprava}

\subsection{Infracrvena spektroskopija s Fourierovom transformacijom}

Infracrvena spektroskopija s Fourierovom transformacijom primijenjena je s ciljem određivanja interakcija između PEO-a i NaAlg-a, koje se manifestiraju pomakom karakterističnih vibracijskih vrpci prema većim ili manjim valnim brojevima. Među mogućim interakcijama je vodikova veza, koja se može javiti između OH skupine NaAlg-a (proton donor) i atoma kisika eterske skupine PEO-a (proton akceptor), što je preduvjet za ostvarivanje mješljivosti polimera. Na slici 2 prikazani su primjeri FT-IR spektara filmova PEO/NaAlg mješavina s označenim značajnim vibracijskim vrpcama, a pripadajući valni brojevi minimuma vibracijskih vrpci dani su u tablici 2.

Prahovi PEO-a i NaAlg-a analizirani su s ciljem utvrđivanja velikih odstupanja filmova čistih polimera od strukture početnih sirovina uslijed utjecaja postupka priprave filmova (npr. razgradnja filmova uslijed duljeg sušenja u vakuumu pri $40{ }^{\circ} \mathrm{C}$ ), ali i kako bi se dobio uvid u strukturu izvornih materija za pripravu filmova. Prema podatcima u tablici 2 nisu uočene značajne razlike između PEO praha i 100PEO/0NaAlg filma, a usporedba NaAlg praha i filma čistog NaAlg-a nije bila moguća jer se nije mogao pripraviti u obliku filma. Za daljnja istraživanja iznimno je važno uspješno pripraviti film čistog NaAlg-a kako bi se bolje uočio utjecaj NaAlg-a na strukturu i svojstva PEO-a u filmu mješavina. Kod filma čistog PEO-a uočavaju se slabo izražene apsorpcijske vrpce oko 3500 i $1635 \mathrm{~cm}^{-1}$, ali zbog nepouzdanog određivanja apsorpcijskog maksimuma nisu prikazane u tablici 2. Uočene vrpce pripadaju istezanju $\mathrm{OH}$ skupine i strižnoj deformaciji $\mathrm{HOH}^{12}$ Navedeno ukazuje na prisutnost iznimno male količine vode, tj. otapala u filmu čistog PEO-a. Prema literaturi, karakteristične vibracijske vrpce $\mathrm{PEO}-\mathrm{a}$ pri $840 \mathrm{~cm}^{-1}$ pripadaju strižnoj deformaciji $\mathrm{C}-\mathrm{O}-\mathrm{C}$ skupine a pri $1100 \mathrm{~cm}^{-1}$ asimetričnom istezanju $\mathrm{C}-\mathrm{O}-\mathrm{C}$ skupine, dok NaAlg ima karakteristične vibracijske vrpce simetričnog i asimetričnog istezanja $\mathrm{COO}^{-}$skupine pri 1415 i $1613 \mathrm{~cm}^{-1}$ te istezanja $\mathrm{OH}$ skupine pri $3500 \mathrm{~cm}^{-1} \cdot{ }^{10} \mathrm{Na}$ FT-IR spektrima filmova $\mathrm{PEO} / \mathrm{NaAlg}$ mješavina javljaju se karakteristične vibracijske vrpce pojedinog polimera, a intenzitet im je propor- 


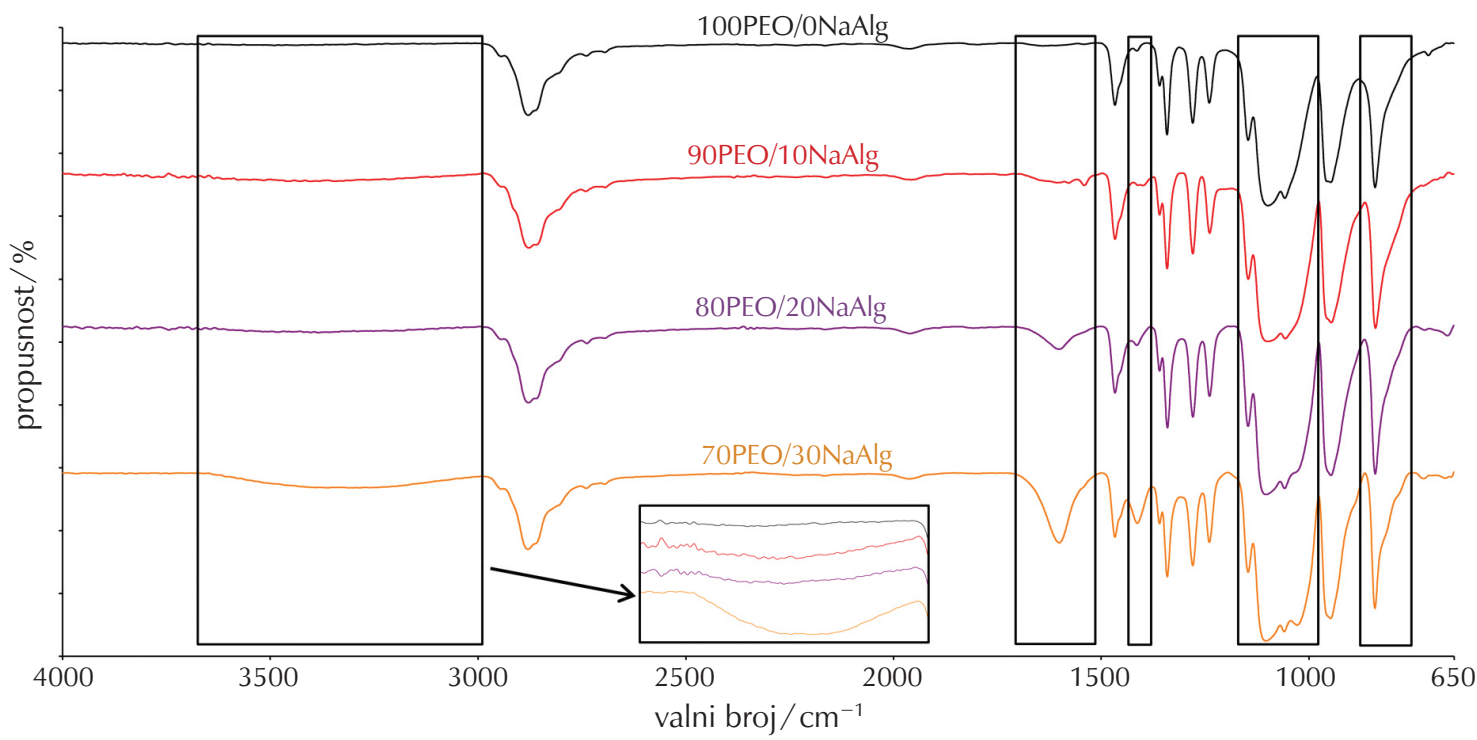

Slika 2 - Primjeri FT-IR spektara filmova PEO/NaAlg mješavina

Fig. 2 - Examples of FT-IR spectra of PEO/NaAlg blend films

Tablica 2 - Valni brojevi vibracijskih vrpci filmova PEO/NaAlg mješavina

Table 2 - Wave numbers of characteristic vibrations of PEO/NaAlg film blends

\begin{tabular}{|c|c|c|c|c|c|}
\hline $\begin{array}{l}\text { Uzorak } \\
\text { Sample }\end{array}$ & $\begin{array}{c}\mathrm{O}-\mathrm{H} \text { istezanje } \\
\mathrm{O}-\mathrm{H} \text { stretching } \\
/ \mathrm{cm}^{-1}\end{array}$ & $\begin{array}{l}\text { Asimetrično } \\
\mathrm{COO}^{-} \text {istezanje } \\
\text { Asymmetric } \\
\text { stretching } \\
{\text { of } \mathrm{COO}^{-}}^{/ \mathrm{cm}^{-1}}\end{array}$ & $\begin{array}{c}\text { Simetrično } \\
\mathrm{COO}^{-} \text {istezanje } \\
\text { Symmetric } \\
\text { stretching } \\
\text { of } \mathrm{COO}^{-} \\
/ \mathrm{cm}^{-1}\end{array}$ & $\begin{array}{c}\text { Asimetrično } \mathrm{C}-\mathrm{O}-\mathrm{C} \\
\text { istezanje (triplet) } \\
\text { Asymmetric stretching } \\
\text { of } \mathrm{C}-\mathrm{O}-\mathrm{C} \text { (triplet) } \\
/ \mathrm{cm}^{-1}\end{array}$ & $\begin{array}{c}\text { Strižna deformacija } \\
\mathrm{C}-\mathrm{O}-\mathrm{C} \\
\text { Scissoring vibration } \\
\text { of } \mathrm{C}-\mathrm{O}-\mathrm{C} \\
/ \mathrm{cm}^{-1}\end{array}$ \\
\hline NaAlg prah & 3210 & 1592 & 1404 & - & - \\
\hline PEO prah & - & - & - & $1145 / 1089 / 1056$ & 839 \\
\hline 100PEO/0NaAlg & - & - & - & 1145/1097/1057 & 840 \\
\hline 95PEO/5NaAlg & 3500 & 1628 & 1413 & 1145/1099/1056 & 839 \\
\hline 90PEO/10NaAlg & 3430 & 1605 & 1412 & 1145/1098/1056 & 839 \\
\hline 85PEO/15NaAlg & 3400 & 1604 & 1414 & $1145 / 1100 / 1056$ & 839 \\
\hline 80PEO/20NaAlg & 3380 & 1601 & 1414 & $1146 / 1103 / 1058$ & 839 \\
\hline 75PEO/25NaAlg & 3380 & 1604 & 1413 & $1145 / 1104 / 1058$ & 840 \\
\hline 70PEO/30NaAlg & 3380 & 1600 & 1412 & $1146 / 1103 / 1058$ & 840 \\
\hline 65PEO/35NaAlg & 3300 & 1596 & 1397 & 1146/1102/1059 & 840 \\
\hline
\end{tabular}

cionalan udjelu polimera u mješavini, kao što se vidi na slici 2. S obzirom na to da se NaAlg dodaje PEO-u, najprije će se promotriti utjecaj NaAlg-a na asimetrično $\mathrm{C}-\mathrm{O}-\mathrm{C}$ istezanje (triplet) i strižnu deformaciji $\mathrm{C}-\mathrm{O}-\mathrm{C}$ skupine PEO-a. Asimetrično $\mathrm{C}-\mathrm{O}-\mathrm{C}$ istezanje (triplet) kod filma 100PEO/0NaAlg javlja se pri 1145, 1097 i $1057 \mathrm{~cm}^{-1}$ te se samo valni broj pri $1097 \mathrm{~cm}^{-1}$ pomiče prema većim valnim brojevima (do $1104 \mathrm{~cm}^{-1}$ ) povećanjem udjela NaAlg-a do 25 mas. \%. Daljnjim povećanjem udjela NaAlg-a dolazi do blagog snižavanja valnih brojeva, tablica 2. Ostala dva valna broja se značajno ne mijenjaju.

G. Patel $i$ sur. ${ }^{7}$ istraživali su mješljivost između PEO-a i poli(akrilamida) te su pratili samo promjenu jednog valnog broja tripleta, tj. valnog broj pri $1106 \mathrm{~cm}^{-1}$. Uočeno pomicanje navedenog valnog broja ukazalo im je na postojanje intermolekulnih interakcija između polimera u mješavini, tj. uspostavljanje vodikove veze. Navedeno su uočili i T. Çaykara $i$ sur. ${ }^{10}$ istražujući filmove $\mathrm{PEO} / \mathrm{NaAlg}$ veće molekulne mase i to pripisali vodikovoj vezi kao temeljnom mehanizmu ostvarivanja mješljivosti PEO-a i NaAlg-a. Navedeni triplet je i odraz postojanja kristalne faze kod PEO-a. ${ }^{11}$ Strižna deformacija $\mathrm{C}-\mathrm{O}-\mathrm{C}$ koja pripada $\mathrm{PEO}-\mathrm{u}$ javlja se pri $840 \mathrm{~cm}^{-1}$ i ne mijenja se povećanjem udjela NaAlg-a kod filmova svih mješavina, tablica 2.

Nove vrpce koje se javljaju uslijed dodavanja NaAlg-a pripadaju istezanju $\mathrm{OH}$ skupine, asimetričnom i simetričnom 
$\mathrm{COO}^{-}$istezanju, slika 2 i tablica 2. Određivanje istezanja $\mathrm{OH}$ skupine je otežano jer su vibracijske vrpce iznimno široke i tek su kod većih udjela NaAlg-a intenzivnije, ali se ipak može uočiti pomicanje prema nižim valnim brojevima povećanjem udjela NaAlg-a u filmovima mješavina, tablica 2. T. Çaykara $i$ sur. ${ }^{10}$ uočili su iste promjene, ali se povećanjem udjela NaAlg-a u filmovima mješavina širi apsorpcijsko područje hidroksilne skupine, pri čemu su sve to naveli kao potvrdu vodikove veze između PEO-a i NaAlg-a. Povećanjem udjela NaAlg-a u filmovima PEO/ $\mathrm{NaAlg}$ mješavina asimetrično istezanje $\mathrm{COO}^{-}$se pomiče prema nižim valnim brojevima uz povećanje intenziteta, slika 2 i tablica 2. Simetrično istezanje $\mathrm{COO}^{-}$skupine javlja se oko $1413 \mathrm{~cm}^{-1}$ i ne uočava se promjena povećanjem udjela NaAlg-a u filmovima mješavina do 30 mas. \%, a dodatkom 35 mas. \% dolazi do pomaka od čak $16 \mathrm{~cm}^{-1}$, tablica 2. Ako je u filmovima mješavina zaostalo otapalo, promjene koje su uočene kod apsorpcijskih vrpci NaAlg-a ne mogu se uzeti kao potvrda vodikove veze (preklapanje s apsorpcijskim vrpcama vode). Za određivanje zaostalog otapala u filmovima primijenit će se TG analiza. Međutim, promjene uočene kod PEO-a u mješavinama ukazuju na uspostavljanje vodikove veze kao temeljnih interakcija PEO-a i NaAlg-a.

\subsection{Diferencijalna pretražna kalorimetrija}

Primjenom diferencijalne pretražne kalorimetrije istraživan je utjecaj NaAlg-a na toplinska svojstva i kristalnost PEO-a, s naglaskom na utjecaj NaAlg-a na kristalnost PEO-a u filmovima $\mathrm{PEO} / \mathrm{NaAg}$ mješavina. Na slici 3 prikazani su primjeri DSC krivulja prvog zagrijavanja, hlađenja i drugog zagrijavanja filmova mješavina.
Krivulje prvog zagrijavanja odraz su utjecaja toplinske prošlosti filmova mješavina i utjecaja NaAlg-a na toplinska svojstva i kristalnost PEO-a, a krivulje drugog zagrijavanja predstavljaju samo utjecaj NaAlg-a na toplinska svojstva i kristalnost PEO-a. Značajke DSC krivulja prvog zagrijavanja i hlađenja ispitaka filmova PEO/NaAlg mješavina dane su u tablici 3, a za drugo zagrijavanje u tablici 4. I kod DSC mjerenja provedena je analiza izvornih PEO i NaAlg prahova kako bi se uočio utjecaj postupka priprave filmova na svojstva mješavina, ali i dobio uvid u toplinska svojstva početnih tvari. Na prvom mjestu misli se na razgradnju uslijed duljeg sušenja filmova pri $40{ }^{\circ} \mathrm{C}$, čiji bi rezultat bila promjena toplinskih značajki. Značajke DSC krivulja PEO praha i 100PEO/0NaAlg filma ne razlikuju se značajnije nakon uklanjanja toplinske prošlosti materijala, tablice 3 i 4 . Promjene koje su uočene primarno se odnose na oblik faznog prijelaza te pojavljivanje malog endotermnog pika ili ramena na glavnom piku taljenja i malog egzotermnog ramena na glavnom piku kristalizacije kod filma 100PEO/0NaAlg (film čistog PEO), slika 3. Uočena razlika vjerojatno je posljedica taljenja i kristalizacije kristala PEO-a različitih veličina i toplinske stabilnosti. Prah NaAlg-a u ispitivanom temperaturnom području ne pokazuje fazne prijelaze.

Kod filmova PEO/NaAlg mješavina (tablica 3) ekstrapolirana početna temperatura taljenja $\left(T_{\text {eim1 }}\right)$ PEO-a se dodatkom NaAlg-a poveća s 57 na $61^{\circ} \mathrm{C}$, a daljnjim povećanjem udjela NaAlg-a snižava se na $58{ }^{\circ} \mathrm{C}$, tj. vraća se na vrijednost PEO-a u filmu 100PEO/ONaAlg. Navedeno ukazuje na različito djelovanje pojedinih udjela NaAlg-a na toplinska svojstva PEO-a. Temperatura u vršku endoterme taljenja $\left(T_{\mathrm{pm} 1}\right)$ PEO-a povećanjem udjela NaAlg-a u mješavini snižava se sa 76 na $70{ }^{\circ} \mathrm{C}$ i ukazuje na mješljivost PEO-a i NaAlg-a. Kad se polimerna mješavina sastoji od krista-

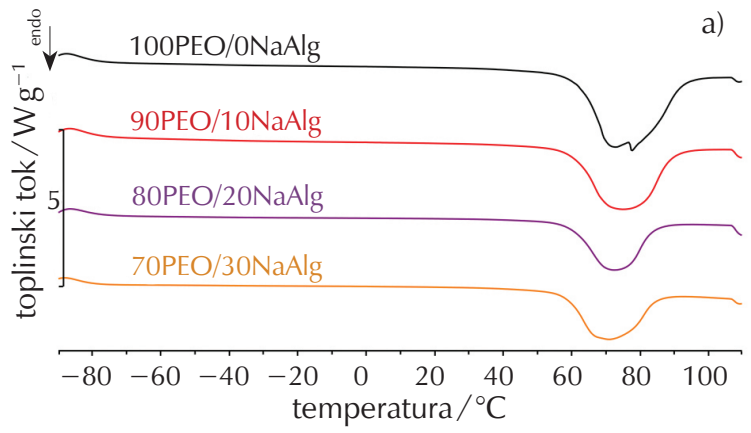

a)

b)
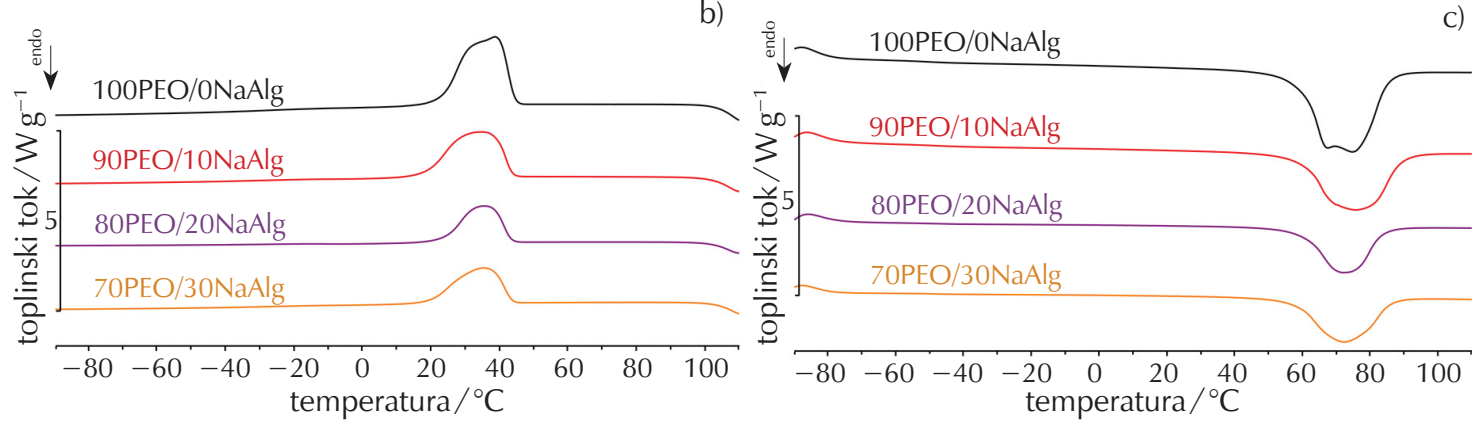

Slika 3 - Primjeri DSC krivulja filmova PEO/NaAlg mješavina: a) prvo zagrijavanje, b) hlađenje i c) drugo zagrijavanje Fig. 3 - Examples of DSC curves of PEO/NaAlg blend films: a) first heating, b) cooling and c) second heating 
Tablica 3 - Značajke DSC krivulja prvog zagrijavanja i hlađenja filmova PEO/NaAlg mješavina Table 3 - DSC characteristics of the first heating and cooling curve of PEO/NaAlg film blends

\begin{tabular}{c|c|c|c|c|c|c|c}
\hline $\begin{array}{c}\text { Uzorak } \\
\text { Sample }\end{array}$ & $T_{\text {eim } 1} /{ }^{\circ} \mathrm{C}$ & $T_{\mathrm{pm} 1} /{ }^{\circ} \mathrm{C}$ & $-\Delta H_{\mathrm{m} 1} / \mathrm{Jg}^{-1}$ & $X_{\mathrm{c} 1} / \%$ & $T_{\text {eimc }} /{ }^{\circ} \mathrm{C}$ & $T_{\mathrm{pmc}} /{ }^{\circ} \mathrm{C}$ & $\Delta H_{\mathrm{mc}} / \mathrm{Jg}$ \\
\hline NaAlg prah & - & - & - & - & - & - \\
\hline PEO prah & 62 & 82 & 169,4 & 90 & 42 & 28 & 132,0 \\
\hline 100PEO/0NaAlg & 57 & 76 & 152,2 & 81 & 45 & 40 & 131,3 \\
\hline 95PEO/5NaAlg & 61 & 75 & 125,0 & 70 & 43 & 34 & 101,9 \\
\hline 90PEO/10NaAlg & 61 & 74 & 124,1 & 73 & 44 & 35 & 103,0 \\
\hline 85PEO/15NaAlg & 59 & 75 & 122,4 & 77 & 43 & 32 & 103,9 \\
\hline 80PEO/20NaAlg & 60 & 72 & 76,2 & 51 & 43 & 36 & 62,7 \\
\hline 75PEO/25NaAlg & 59 & 73 & 80,4 & 57 & 44 & 35 & 67,9 \\
\hline 70PEO/30NaAlg & 58 & 70 & 81,2 & 62 & 44 & 36 & 69,8 \\
\hline 65PEO/35NaAlg & 58 & 70 & 62,3 & 51 & 43 & 37 & 54,6 \\
\hline
\end{tabular}

Tablica 4 - Značajke DSC krivulja drugog zagrijavanja filmova PEO/NaAlg mješavina

Table 4 - DSC characteristics of the second heating curve of PEO/NaAlg film blends

\begin{tabular}{|c|c|c|c|c|c|c|c|}
\hline $\begin{array}{l}\text { Uzorak } \\
\text { Sample }\end{array}$ & $T_{\text {eig }} /{ }^{\circ} \mathrm{C}$ & $T_{\mathrm{mg}} /{ }^{\circ} \mathrm{C}$ & $\Delta c_{p} / \mathrm{Jg}^{-1{ }^{\circ} \mathrm{C}^{-1}}$ & $T_{\text {eim } 2} /{ }^{\circ} \mathrm{C}$ & $T_{\mathrm{pm} 2} /{ }^{\circ} \mathrm{C}$ & $-\Delta H_{\mathrm{m} 2} / \mathrm{Jg}^{-1}$ & $X_{\mathrm{c} 2} / \%$ \\
\hline NaAlg prah & - & - & - & - & - & - & - \\
\hline PEO prah & -56 & -51 & 0,06 & 58 & 81 & 136,1 & 73 \\
\hline 100PEO/0NaAlg & -54 & -50 & 0,10 & 55 & 73 & 135,2 & 72 \\
\hline 95PEO/5NaAlg & -52 & -49 & 0,08 & 59 & 77 & 106,2 & 59 \\
\hline 90PEO/10 NaAlg & -52 & -48 & 0,09 & 60 & 75 & 105,8 & 62 \\
\hline 85PEO/15NaAlg & -52 & -48 & 0,09 & 59 & 75 & 104,2 & 65 \\
\hline 80PEO/20NaAlg & -53 & -47 & 0,06 & 60 & 72 & 63,3 & 42 \\
\hline $75 \mathrm{PEO} / 25 \mathrm{NaAlg}$ & -52 & -47 & 0,03 & 59 & 75 & 68,9 & 49 \\
\hline 70PEO/30 NaAlg & -53 & -47 & 0,06 & 58 & 72 & 70,4 & 53 \\
\hline $65 \mathrm{PEO} / 35 \mathrm{NaAlg}$ & - & - & - & 58 & 72 & 54,3 & 44 \\
\hline
\end{tabular}

lastog i amorfnog polimera, snižavanje temperature taljenja ukazuje na postojanje interakcija između polimera. ${ }^{13}$ Prethodno spomenuti dodatni pik ili rame na glavnoj endotermi taljenja filma 100PEO/ONaAlg javlja se pri $71^{\circ} \mathrm{C}$. Manji i nesavršeni kristali tale se pri nižim temperaturama, za razliku od većih i savršenih kristala. ${ }^{14}$ Toplina taljenja $\left(\Delta H_{\mathrm{m} 1}\right)$ PEO-a se dodatkom NaAlg-a naglo snizi s 152,2 na $125,0 \mathrm{~J} \mathrm{~g}^{-1}$, nakon čega slijedi daljnje snižavanje vrijednosti povećanjem udjela NaAlg-a do 15 mas. \% u mješavini. Dodatkom 20 mas. \% NaAlg-a mješavini ponovno dolazi do velike promjene $\Delta H_{\mathrm{m} 1}$ od 122,4 do $76,2 \mathrm{Jg}^{-1}$, a zatim se vrijednosti $\Delta H_{\mathrm{m} 1}$ daljnjim povećanjem udjela NaAlg-a nalaze $\mathrm{u}$ rasponu od $80,4 \mathrm{do} 62,3 \mathrm{~J} \mathrm{~g}^{-1}$. Promjena topline taljenja dijelom je, naravno, rezultat smanjenja udjela PEO-a u mješavini, ali i sposobnosti NaAlg-a da ometa kristalizaciju PEO-a. Iz promjene vrijednosti stupnja kristalizacije $\left(X_{\mathrm{c} 1}\right)$ PEO-a kod mješavina teško je zaključiti na koji način promjena udjela NaAlg-a u mješavini utječe na kristalizaciju PEO-a. Može se općenito zaključiti da su vrijednost $X_{\mathrm{c} 1}$ PEO-a ovisne o udjelu NaAlg-a u mješavini i da su manje u odnosu na film čistog PEO-a. Najmanja vrijednost od $51 \%$ javlja se kod filmova mješavina s 20 i 35 mas. \% NaAlg-a, tablica 3. Cilj istraživanja je smanjivanje udjela kristalne faze PEO-a u filmu zbog postizanja bolje provodnosti PEO-a kad se u njega doda litijeva sol, što se najbolje postiglo kod prethodno navedene dvije mješavine (80PEO /20NaAlg i 65PEO/35 NaAlg).

Kristalizacija iz taline javlja se kod svih filmova PEO/NaAlg mješavina, slika 3 i tablica 3. Vrijednost ekstrapolirane početne temperature kristalizacije iz taline ( $\left.T_{\text {eimc }}\right)$ PEO-a povećavanjem udjela NaAlg-a u mješavini ne mijenja se značajno. Temperatura kristalizacije iz taline u vršku egzoterme $\left(T_{\text {pmc }}\right)$ PEO-a dodatkom NaAlg-a snizi se za $6{ }^{\circ} \mathrm{C}$, dok se kod ostalih filmova mješavina nalazi u rasponu od 32 do $37{ }^{\circ} \mathrm{C}$, pri čemu treba naglasiti da je najniža kod mješavine s 15 mas. \% NaAlg-a. Uz glavni pik kristalizacije iz taline, kod filma 100PEO/0NaAlg pojavljuje se malo rame pri $36{ }^{\circ} \mathrm{C}$, što je već uočeno kod PEO-a manjih molekulnih masa, a razlog je u nastajanju kristala koji se mijenjaju tijekom kristalizacije uslijed zadebljavanja ili sta- 
njivanja. ${ }^{15}$ Toplina kristalizacije iz taline $\left(\Delta H_{\mathrm{mc}}\right)$ PEO-a dodatkom NaAlg-a snizi se od 131,3 do 101,9 J g ${ }^{-1}$ te ostaje približno ista povećanjem udjela NaAlg-a u mješavini do 15 mas. \%, nakon čega ponovno slijedi velika promjena s dodatkom 20 mas. \% NaAlg-a. Vrijednost $\Delta H_{\text {mc }}$ snizi se za oko $40 \mathrm{~J} \mathrm{~g}^{-1}$, a daljnjim povećavanjem udjela NaAlg-a u mješavini ostaje u rasponu od 54,6 do 69,8 J g ${ }^{-1}$. Niže vrijednosti $T_{\mathrm{pmc}}$ i $\Delta H_{\mathrm{mc}}$ PEO-a kod filmova mješavina u odnosu na film čistog PEO-a (100PEO/ONaAlg) jasno ukazuju na djelovanje NaAlg-a kao prepreke kristalizaciji PEO-a.

Ekstrapolirana početna temperatura staklastog prijelaza $\left(T_{\text {eig }}\right)$ i temperatura staklastog prijelaza pri kojoj je promjena toplinskog kapaciteta jednaka polovini njegove maksimalne vrijednosti $\left(T_{\mathrm{mg}}\right)$ PEO-a blago se mijenjaju s dodatkom NaAlg-a, tj. njihove vrijednosti su niže za 2 do $3{ }^{\circ} \mathrm{C}$ od filma 100PEO/ONaAlg, tablica 4. lako je promjena staklišta povećanjem udjela NaAlg-a u mješavini mala, ipak ukazuje na postojanje interakcija između PEO-a i NaAlg-a koje vode ka mješljivosti sustava a također su uočene FT-IR spektroskopijom. S. Kuo ${ }^{16}$ je u svojem preglednom radu prikazao utjecaj vodikove veze na mješljivost različitih polimera. Osim ostalog ukazao je i na depresiju staklišta kao rezultat mješljivosti, koja se često javlja kod polimernih elektrolita kao što je PEO. Vrijednosti promjene specifičnog toplinskog kapaciteta $\left(\Delta c_{\mathrm{p}}\right)$ PEO-a nalaze se u području od 0,03 do $0,10 \mathrm{~J} \mathrm{~g}^{-1} \mathrm{~K}^{-1}$, a smanjuju se povećanjem udjela NaAlg-a u mješavini, tablica 4. Filmovi mješavina brže će se zagrijavati od filma čistog PEO-a, što bi moglo dovesti do njihove lošije toplinske postojanosti. Dodatkom NaAlg-a vrijednost $T_{\text {eim2 }}$ PEO-a se poveća s 55 na $59{ }^{\circ} \mathrm{C}$ te ostaje približno jednaka povećanjem udjela NaAlg-a u mješavini, tablica 4 . Vrijednost $T_{\mathrm{pm} 2}$ PEO-a također dodatkom NaAlg-a najprije poraste za $4{ }^{\circ} \mathrm{C}$ te se daljnjim povećanjem udjela NaAlg-a u mješavini postupno snižava od 77 na $72{ }^{\circ} \mathrm{C}$ uz iznimku kod filma mješavine s 20 mas. \% NaAlg-a. Nakon uklanjanja toplinske prošlosti materijala i dalje se uočavaju iste promjene temperature taljenja PEO-a pod utjecajem NaAlg-a. I kod drugog zagrijavanja se uz glavnu endotermu taljenja kod filma 100PEO/ONaAlg mješavine može vidjeti rame pri oko $66^{\circ} \mathrm{C}$, slika 3 . Rame također može ukazivati na stvaranje lamela manjih debljina tijekom nastajanja kristala PEO-a uz široku distribuciju debljina lamela, pri čemu se temperiranjem može regulirati kristalizacija PEO-a. ${ }^{17}$ Pojavljivanje ramena na glavnom endotermnom prijelazu ima velik utjecaj na vrijednost $T_{\mathrm{pm} 2}$ PEO-a, koja pak služi kao referenta vrijednost za određivanje mješljivosti između PEO-a i NaAlg-a. Također, uočena je slična promjena vrijednosti $\Delta H_{\mathrm{m} 2}$ PEO-a dodatkom i povećanjem udjela NaAlg-a u mješavini kao i kod prvog zagrijavanja. Vrijednost $\Delta H_{\mathrm{m} 2}$ PEO-a se dodatkom NaAlg-a naglo snizi od 135,2 do 106,2 J g ${ }^{-1}$ nakon čega slijedi daljnje snižavanje vrijednosti povećanjem udjela NaAlg-a u mješavini do 15 mas. \%. Dodatkom 20 mas. \% NaAlg-a PEO-u ponovno dolazi do velike promjene $\Delta H_{\mathrm{m} 2}$ PEO-a od 104,2 do 63,3 J g ${ }^{-1}$, a zatim se vrijednosti $\Delta H_{\mathrm{m} 2}$ PEO-a daljnjim povećanjem udjela $\mathrm{NaAlg-a}$ nalaze $\mathrm{u}$ rasponu od 70,4 do 54,3 J g ${ }^{-1}$. Nakon uklanjanja toplinske prošlosti filmova potvrđeno je ometanje kristalizacije PEO-a dodatkom NaAlg-a. C. Tonin i sur. ${ }^{18}$ također su uočili ometanje kristalizacije PEO-a dodatkom keratina. I kod drugog zagrijavanja filmova $\mathrm{PEO} / \mathrm{NaAlg}$ mješavina iz vrijednosti $X_{\mathrm{c} 2}$ PEO-a ne može se zaključiti na koji način promjena udjela NaAlg-a u mješavini utječe na kristalizaciju PEO-a, ali se može uočiti da su vrijednosti $X_{c 2}$ PEO-a u filmovima mješavina manje od vrijednosti $X_{\mathrm{c} 2}$ filma 100PEO/0NaAlg (film čistog PEO-a), tablica 4. Najmanja vrijednost stupnja kristalnosti od $42 \%$ postignuta je kod filma mješavine s 20 mas. \% NaAlg-a (80PEO/20NaAlg). M. S. Bostan $i$ sur. ${ }^{6}$ istraživali su mješavine kitozana, PEO-a i levana te zaključili da je blago snižavanje $T_{\mathrm{m}}$ i značajno smanjivanje udjela kristalne faze PEO-a rezultat postojanja vodikovih veza između polimera u mješavini, pri čemu kitozan i levan u ispitivanom području ne pokazuju taljenje, kao što je slučaj kod NaAlg-a.

Istraživanje utjecaja NaAlg-a na kristalnost filmova PEO-a ukazalo je na to da najveći potencijal za pripravu SPE-a s litijevim solima ima mješavina 80PEO/20NaAlg. Kod te mješavine postignuto je najveće smanjenje udjela kristalne faze PEO-a zbog prisutnosti NaAlg-a. U slučaju $X_{\mathrm{c} 1}$ udio kristalne faze PEO-a u mješavini smanjio se za čak $63 \%$ u odnosu na film čistog PEO-a, a u slučaju $X_{\text {c2 }}$ za $58 \%$. Također, film navedene mješavine izgledao je najbolje nakon sušenja u vakuumskom sušioniku, bio je jednake debljine, proziran, fleksibilan te se najlakše odvajao od Petrijeve zdjelice. Zabilježene depresije tališta i staklišta ukazuju na mješljivost PEO-a i NaAlg-a te potvrđuju zaključke FT-IR spektroskopije.

\subsection{Neizotermna termogravimetrija}

Važno je dobro poznavati toplinsku postojanost čvrstih polimernih elektrolita pa tako i PEO/NaAlg mješavina. Minimalna toplinska postojanost koja se zahtijeva od SPE-a je $150{ }^{\circ} \mathrm{C} .{ }^{1}$ Toplinska razgradnja provedena je primjenom neizotermne termogravimetrije, a primjeri dobivanih TG i pripadajućih DTG krivulja filmova PEO/NaAlg mješavina prikazani su na slikama 4 i 5. Značajke TG i DTG krivulja prikazane su u tablici 5. Prahovi PEO-a i NaAlg-a također su ispitani na toplinsku postojanost zbog moguće razgradnje uzrokovane dugotrajnim sušenjem filmova pri $40{ }^{\circ} \mathrm{C}$.

Prahovi PEO-a i suhog NaAlg-a razgrađuju se u jednom stupnju razgradnje, tablica 5. Prah NaAlg-a razgrađuje se pri znatno nižim temperaturama od praha $\mathrm{PEO}-\mathrm{a}$, razlika je oko $150{ }^{\circ} \mathrm{C}$ i ima veliku ostatnu masu $\left(m_{\mathrm{f}}=40 \%\right)$, za razliku od praha PEO-a (3,9\%), tablica 5. Film 100PEO /ONaAlg (film čistog PEO-a) razgrađuje se u jednom stupnju razgradnje u području od 350 do $450{ }^{\circ} \mathrm{C}$, slike 4 i 5 . Temperatura pri kojoj gubi $5 \%$ početne mase $\left(T_{5 \%}\right)$, temperatura početka razgradnje $\left(T_{\text {onset }}\right)$ i temperatura pri maksimalnoj brzini razgradnje $\left(T_{\max }\right)$ iznose 326,395 i $417^{\circ} \mathrm{C}$. Vrijednosti mase ispitka pri temperaturi početka razgradnje $\left(m_{\text {onset }}\right)$, mase ispitaka pri temperaturi maksimalne brzine razgradnje $\left(m_{\max }\right)$ i ostatna masa $\left(m_{\mathrm{f}}\right)$ iznose 100,0 , 36,5 i $6,5 \%$, dok maksimalna brzina razgradnje $(\mathrm{dm} / \mathrm{d} T)_{\max }$ iznosi $28,9 \%{ }^{\circ} \mathrm{C}^{-1}$. Treba napomenuti da se kod filma 100PEO/0NaAlg na TG i DTG krivuljama uočava izrazito mali gubitak mase u širokom temperaturnom području prije razgradnje PEO-a koje se pripisuje isparavanju zaostalog otapala (voda) u filmu, ali zbog slabo izraženog prijelaza podatci se nisu mogli pouzdano odrediti i prikazati u tablici 5. Naznake zaostalog otapala uočene su i FT-IR spektroskopijom. Uočeno isparavanje vode napravilo je malu razliku između toplinskih značajki praha PEO-a i fil- 


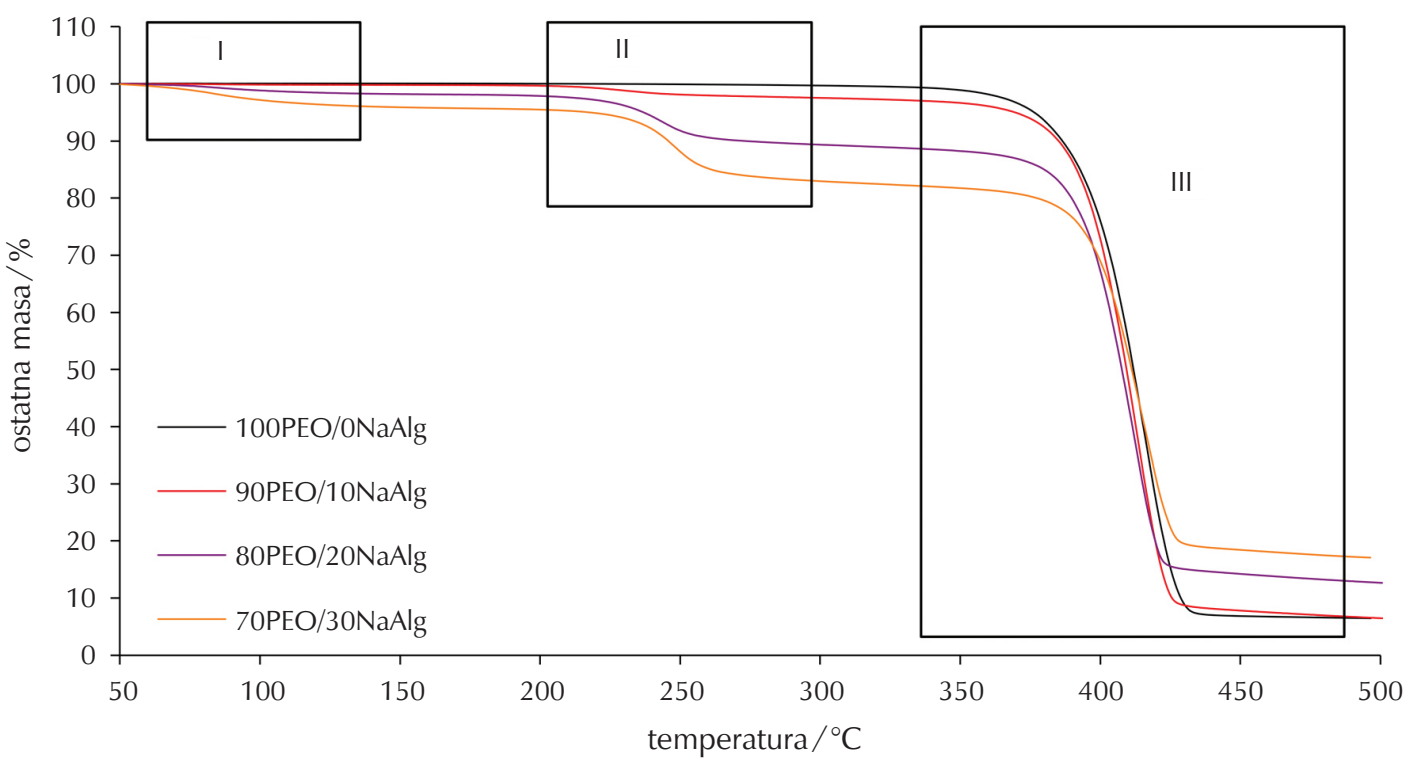

Slika 4 - Primjeri TG krivulja filmova PEO/NaAlg mješavina

Fig. 4 - Examples of TG curves of PEO/NaAlg blend films

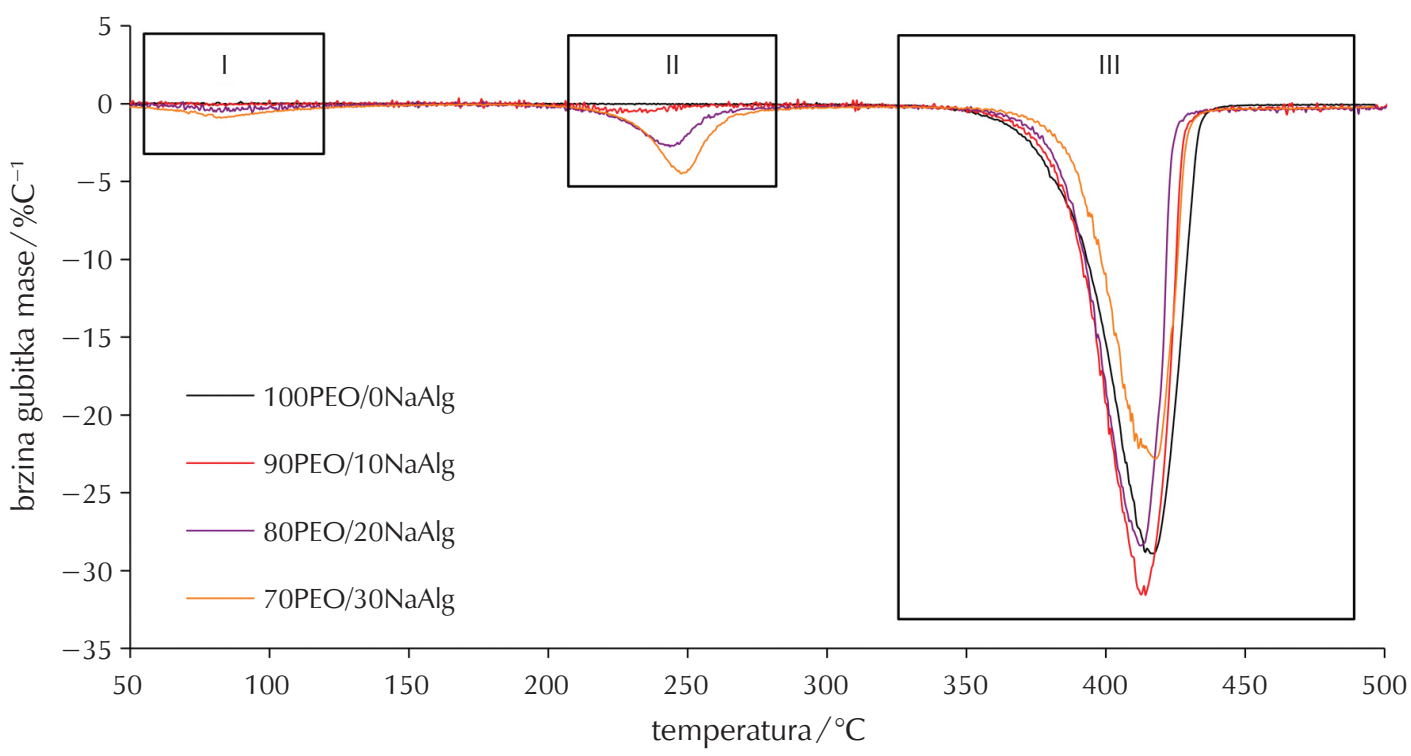

Slika 5 - Primjeri DTG krivulja filmova PEO/NaAlg mješavina

Fig. 5 - Examples of DTG curves of PEO/NaAlg blend films

ma 100PEO/0NaAlg, ali ne ukazuje na razgradnju PEO-a tijekom postupka priprave filma.

Filmovi PEO/NaAlg mješavina razgrađuju se u više stupnjeva razgradnje, kao što je i označeno na primjerima TG i DTG krivulja na slikama 4 i 5 (rimski brojevi I - III označavaju razgradnju koja se odvija u određenom temperaturnom području, tj. razgradnju pojedine komponente mješavine; I zaostala voda, II NaAlg i III PEO). Uslijed nedovoljno osušenih filmova došlo je do zaostajanja malog udjela vode (maks. $5 \%$ ) koji se povećava povećanjem udjela NaAlg-a u mješavini, tablica 5, jer NaAlg ima tendenciju zadržavanja vode unutar svoje molekulne strukture. ${ }^{19}$ Otapalo se ubu- duće može ukloniti optimizacijom postupka sušenja. Treba paziti da prilikom produživanja vremena sušenja u vakuumskom sušioniku ne dođe do razgradnje filmova mješavina. Zbog nastavka sušenja materijala tijekom TG mjerenja, prvi stupanj se neće uzeti u obzir kao stupanj razgradnje filmova. K. M. Anilkumaris $i$ sur. ${ }^{20}$ istraživali su mješavine PEO-a i poli(vinil-pirolidina) (PVP) koje su sadržavale $7 \%$ zaostale vode te su razgradnjom smatrali tek početak razgradnje prvog polimera u mješavini (oko $220^{\circ} \mathrm{C}$ ). Zaostala voda nije predstavljala problem nakon priprave SPE-a s magnezijevom soli, čak suprotno, te su dobili SPE željenih svojstava. Kod filmova mješavina 95PEO/5NaAlg i 90PEO /10NaAlg uočava se zaostala voda, ali ju je također teško 
pouzdano odrediti kao i u slučaju filma 100PEO/0NaAlg. Prisutnost zaostale vode odrazila se na vrijednost $T_{5 \%}$ filmova, pa se ne može uzeti kao indikator početka razgradnje mješavina. Dodatkom NaAlg-a u PEO pojavljuje se razgradnja NaAlg-a (oznaka II na slikama 4 i 5 te tablici 5) uz razgradnju PEO-a (oznaka III), pa su se zasebno i razmatrali kako bi se uočila posljedica interakcija između PEO-a i NaAlg-a uočena prethodnim instrumentalnim tehnikama. NaAlg u filmovima mješavina ima otprilike $200{ }^{\circ} \mathrm{C}$ lošiju toplinsku postojanost od PEO-a u mješavini, tablica 5. U slučaju $T_{\text {onset }}$ NaAlg-a u mješavini (oznaka II) povećanjem udjela NaAlg-a dolazi do postupnog porasta vrijednosti $T_{\text {onset }}$ od 205 do $233{ }^{\circ} \mathrm{C}$, a vrijednost $T_{\text {max }}$ raste od 227 do $249{ }^{\circ} \mathrm{C}$. Poboljšanje toplinske postojanosti NaAlg-a u mješavini ne potvrđuje uspostavljanje interakcija između NaAlg-a i PEO-a, jer se uslijed nemogućnosti usporedbe toplinskih značajki NaAlg-a u mješavini sa značajkama filma čistog NaAlg-a ne može zaključiti je li navedeno odraz samog povećanja udjela NaAlg-u mješavini ili je stvarno došlo do interakcija s PEO-om. M. S. Bostan i sur. ${ }^{6}$ također su utvrdili pomak $T_{\max }$ jedne od triju komponenata (PEO) kitozan/PEO/levan mješavine prema višim temperaturama, što su pripisali nastajanju vodikovih veza između polimera u mješavini. Vrijednosti $m_{\text {onset }}$ i $m_{\max }$ NaAlg-a u mješavini (oznaka II) se povećanjem udjela NaAlg-a u mješavini sni- žavaju, $m_{\text {onset }}$ za maksimalno $5 \%$, a $m_{\max }$ za maksimalno $10 \%$. Vrijednosti $(\mathrm{d} m / \mathrm{d} T)_{\max } \mathrm{NaAlg-a}$ u mješavinama (oznaka II) znatno su niže od odgovarajućih vrijednosti PEO-a u mješavinama, tablica 5. Dodatkom NaAlg-a PEO-u dolazi do razgradnje filmova mješavina pri nižim temperaturama od filma 100PEO/ONaAlg, tj. filmovi mješavina imaju lošiju toplinsku postojanost od filma 100PEO/ONaAlg (čisti PEO) zbog NaAlg-a.

Vrijednosti $T_{\text {onset }}$ i $T_{\max }$ PEO-a u filmovima mješavina (oznaka III) se povećanjem udjela NaAlg-a u mješavini mijenjaju u granicama $\pm 5{ }^{\circ} \mathrm{C}$, a samo se $m_{\text {onset }}$ PEO-a u mješavini mijenja i to snižavanjem vrijednosti maksimalno za $20 \%$, tablica 5. Razgradnja PEO-a u mješavinama usporava se povećanjem udjela NaAlg-a za razliku od razgradnje NaAlg-a u mješavinama. Vrijednosti $m_{\mathrm{f}}$ filmova se povećanjem udjela NaAlg-a u filmovima PEO/NaAlg povećaju sa 6,5 na oko $17,6 \%$, tablica 5 . Razlog tome je prisutnost natrija u strukturi molekule NaAlg-a koji pridonosi stvaranju produkata razgradnje postojanih do $500{ }^{\circ} \mathrm{C}$. J. P. Soares i sur. ${ }^{9}$ u svojem su istraživanju prikazali razgradnju alginske kiseline i natrijeva alginata u području od 25 do $900{ }^{\circ} \mathrm{C}$. Tijekom razgradnje NaAlg-a u području do $500{ }^{\circ} \mathrm{C}$ ostatna masa iznosila je oko $40 \%$ te su utvrdili nastajanje natrijeva karbonata.

Tablica 5 - Značajke TG i DTG krivulja filmova PEO/NaAlg mješavina

Table 5 - TG and DTG characteristics of curves of PEO/NaAlg film blends

\begin{tabular}{|c|c|c|c|c|c|c|c|c|c|}
\hline $\begin{array}{l}\text { Uzorak } \\
\text { Sample }\end{array}$ & $\begin{array}{c}\text { Temperaturno } \\
\text { područje }\end{array}$ & $T_{5 \%} /{ }^{\circ} \mathrm{C}$ & $T_{\text {onset }} /{ }^{\circ} \mathrm{C}$ & $m_{\text {onset }} / \%$ & $T_{\max } /{ }^{\circ} \mathrm{C}$ & $m_{\max } / \%$ & $(\mathrm{~d} m / \mathrm{d} T)_{\max } / \%{ }^{\circ} \mathrm{C}^{-1}$ & $\Delta m / \%$ & $m_{\mathrm{f}} / \%$ \\
\hline NaAlg prah & II & 223 & 239 & 99,8 & 247 & 70,9 & 28,2 & 60,0 & 40,0 \\
\hline PEO prah & III & 366 & 380 & 100,0 & 404 & 40,3 & 25,9 & 96,1 & 3,9 \\
\hline 100PEO/0NaAlg & III & 326 & 395 & 100,0 & 417 & 36,5 & 28,9 & 93,5 & 6,5 \\
\hline \multirow{2}{*}{ 95PEO/5NaAlg } & II & \multirow{2}{*}{319} & 205 & 100,0 & 229 & 98,9 & 0,4 & 2,3 & \multirow{2}{*}{5,9} \\
\hline & III & & 399 & 97,5 & 413 & 35,5 & 31,6 & 91,8 & \\
\hline \multirow{2}{*}{ 90PEO/10NaAlg } & II & \multirow{2}{*}{320} & 202 & 100,0 & 228 & 99,0 & 0,6 & 2,5 & \multirow{2}{*}{6,5} \\
\hline & III & & 395 & 97,4 & 414 & 35,7 & 31,5 & 91,1 & \\
\hline \multirow{3}{*}{ 85PEO/15NaAlg } & 1 & \multirow{3}{*}{128} & 67 & 99,9 & 83 & 99,5 & 0,2 & 1,2 & \multirow{3}{*}{8,5} \\
\hline & II & & 224 & 98,5 & 241 & 95,7 & 1,7 & 6,3 & \\
\hline & III & & 393 & 92,6 & 412 & 38,1 & 29,2 & 84,0 & \\
\hline \multirow{3}{*}{ 80PEO/20NaAlg } & I & \multirow{3}{*}{187} & 67 & 99,9 & 82 & 99,4 & 0,3 & 1,8 & \multirow{3}{*}{12,6} \\
\hline & II & & 226 & 98,2 & 244 & 93,4 & 2,7 & 9,2 & \\
\hline & III & & 394 & 88,9 & 413 & 35,8 & 28,4 & 76,3 & \\
\hline \multirow{3}{*}{ 75PEO/25NaAlg } & 1 & \multirow{3}{*}{181} & 64 & 99,9 & 83 & 98,6 & 0,8 & 3,2 & \multirow{3}{*}{13,4} \\
\hline & II & & 230 & 96,7 & 247 & 91,7 & 2,8 & 9,8 & \\
\hline & III & & 396 & 87,2 & 416 & 36,7 & 26,6 & 73,6 & \\
\hline \multirow{3}{*}{ 70PEO/30NaAlg } & 1 & \multirow{3}{*}{168} & 65 & 99,9 & 83 & 98,3 & 0,9 & 4,3 & \multirow{3}{*}{17,1} \\
\hline & II & & 233 & 95,7 & 249 & 88,8 & 4,5 & 13,2 & \\
\hline & III & & 396 & 82,4 & 418 & 35,1 & 22,8 & 65,4 & \\
\hline \multirow{3}{*}{ 65PEO/35NaAlg } & I & \multirow{3}{*}{136} & 59 & 100,0 & 80 & 98,1 & 1,0 & 4,7 & \multirow{3}{*}{17,6} \\
\hline & II & & 233 & 95,2 & 249 & 88,1 & 4,5 & 13,2 & \\
\hline & III & & 398 & 82,2 & 416 & 37,1 & 24,8 & 64,5 & \\
\hline
\end{tabular}




\subsection{Elektrokemijska impedancijska spektroskopija}

Na slici 6 Nyquistov je prikaz impedancijskih spektara filmova PEO/NaAlg mješavina snimljenih u širokom području frekvencija od $1 \mathrm{MHz}$ do $1 \mathrm{~Hz}$. Uočljiva je linearna ovisnost imaginarne $\left(Z_{\text {imag }}\right)$ o realnoj $\left(Z_{\text {real }}\right)$ komponenti impedancije, gotovo paralelna s ordinatom. Takav impedancijski odziv karakterističan je za neidealni kondenzator čije ponašanje se opisuje konstantno faznim elementom (KFE). Impedancija KFE-a opisana je jedn. (2):

$$
Z_{\mathrm{KFE}}=\left[Q(j \omega)^{n}\right]^{-1}
$$

gdje je $Q$ koeficijent konstantnog faznog elementa, $n$ njegov eksponent, $j=\sqrt{-1}$, a $\omega$ kutna frekvencija. Eksponent $n$ može poprimiti vrijednosti između $1 \mathrm{i}-1$. Za neke specifične vrijednosti $n$, jedn. (2) opisuje otpor $(n=0)$, kapacitet $(n=1)$, induktivitet $(n=-1)$, Warburgovu impedanciju $(n=0,5)$. Eksperimentalno dobiveni impedancijski odziv matematički je usklađen upotrebom električnog ekvivalentnog kruga koji se sastoji od otpornika $R$ serijski vezanog s KFE-om. Numeričke vrijednosti elemenata električkog ekvivalentnog kruga za svaki film određene su matematičkim usklađivanjem primjenom programa ZView.

Vrijednosti eksponenta $n$ KFE za analizirane filmove su između 0,983 i 0,900 (detalj na slici 6), odakle je jasno da KFE opisuje ponašanje neidealnog kondenzatora: što je eksponent $n$ manji neidealnost je veća. Eksperimentalno određena vrijednost eksponenta $n$ snižava se s porastom sadržaja NaAlg-a te ukazuje na to da porast sadržaja NaAlg-a narušava strukturu kondenzatora. Promjena $n \mathrm{~s}$ promjenom sadržaja NaAlg-a ne slijedi u potpunosti promjenu stupnja kristalnosti s porastom sadržaja NaAlg-a. Film 80PEO/20NaAlg mješavine pokazuje najmanji stupanj kristalnosti (tablice 3 i 4), dok se eksponent $n$ kontinuirano smanjuje s porastom sadržaja NaAlg-a. Može se zaključiti da eksponent $n$ odražava uređenost cjelokupne strukture filma. Vrijednosti koeficijenta $Q$ pripisuju se kapacitetu kondenzatora i ovisne su o sadržaju NaAlg-a u mješavini: porastom udjela NaAl-g-a u mješavini raste i kapacitet filma (detalj slika 6).

\section{Zaključak}

Filmovi PEO/NaAlg mješavina pripravljeni su izlijevanjem iz vodenih otopina. Infracrvena spektroskopija s Fourierovom transformacijom ukazala je na postojanje vodikove veze kao temeljnog mehanizma ostvarivanja mješljivosti PEO-a i NaAlg-a. Diferencijalna pretražna kalorimetrija potvrdila je interakcije između polimera koje su dovele do mješljivosti polimera u mješavini. Istraživanje utjecaja NaAlg-a na kristalnost filmova PEO-a ukazalo je na najveće snižavanje udjela kristalne faze kod filma mješavine $80 \mathrm{PEO} / 20 \mathrm{NaAlg}$. Neizotermnom termogravimetrijom utvrđen je mali udio zaostalog otapala, koji ne predstavlja problem u filmovima, ali u budućim istraživanjima nastojat će se optimizirati vrijeme sušenja filmova mješavina. Pripravom filmova mješavina $\mathrm{PEO} / \mathrm{NaAlg}$ dolazi do pogoršanja toplinske posto-

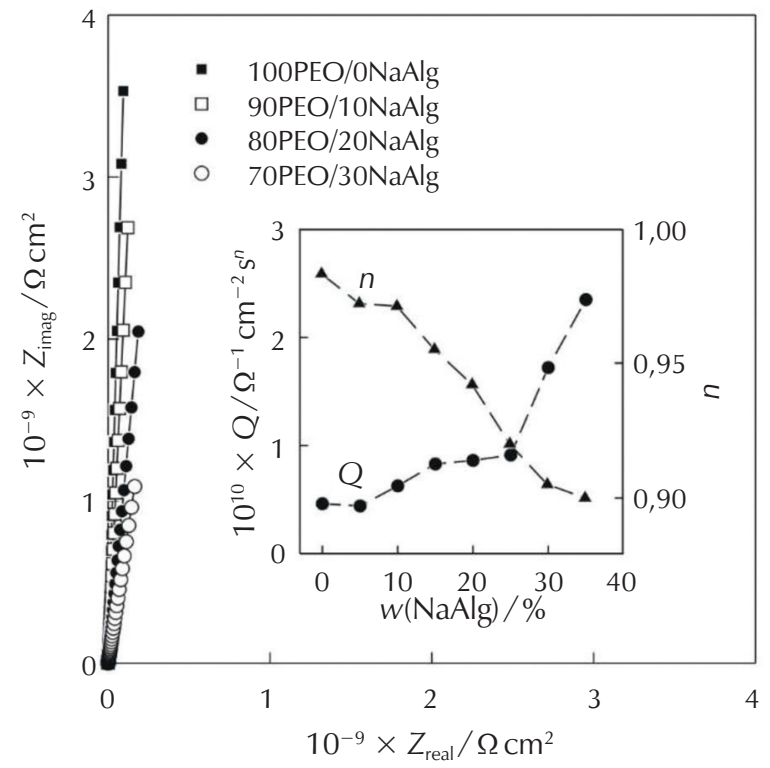

Slika 6 - Nyquistov prikaz impedancijskih spektara filmova PEO/ NaAlg mješavina

Fig. 6 - Nyquist plots of impedance spectra of PEO/NaAlg blend films

janosti filmova zbog dodatka NaAlg-a, ali im je toplinska postojanost i dalje iznad minimalno potrebne toplinske postojanosti SPE-a. Impedancijski odzivi ispitivanih filmova PEO/NaAlg mješavina pokazuju da su filmovi dielektrici, a njihov kapacitet raste s porastom sadržaja NaAlg-a u filmu. Vrijednost eksponenta $n$ konstatntnog faznog elementa upotrijebljenog za matematičko usklađivanje eksperimentalnih podataka odražava uređenost cjelokupne strukture filma. Buduća istraživanja će se usmjeriti na dodatak litijeve soli u mješavinu 80PEO/20NaAlg kako bi se pripravio SPE.

\section{Popis kratica i simbola List of abbreviations and symbols}

$\begin{array}{ll}\text { PEO } & - \text { poli(etilen-oksid) } \\ & - \text { poly(ethylene oxide) } \\ \text { NaAlg } & - \text { natrijev alginat } \\ & - \text { sodium alginate } \\ \text { FT-IR } \quad & - \text { infracrvena spektroskopija s Fourierovom } \\ & \quad \text { transformacijom } \\ & - \text { Fourier transform infrared spectroscopy } \\ \text { DSC } & - \text { diferencijalna pretražna kalorimetrija } \\ & - \text { differential scanning calorimetry } \\ \text { TG } & - \text { termogravimetrija } \\ & - \text { thermogravimetry } \\ \overline{M_{v}} \quad & - \text { viskozni prosjek relativnih molekulnih masa, } \mathrm{g} \mathrm{mol}^{-1} \\ & - \text { viscosity average molecular weight, } \mathrm{g} \mathrm{mol}^{-1} \\ \bar{v} & - \text { valni broj, } \mathrm{cm}^{-1} \\ & - \text { wavenumber, } \mathrm{cm}^{-1} \\ T_{\mathrm{m}} & - \text { temperatura taljenja, }{ }^{\circ} \mathrm{C} \\ & - \text { melting temperature, }{ }^{\circ} \mathrm{C}\end{array}$




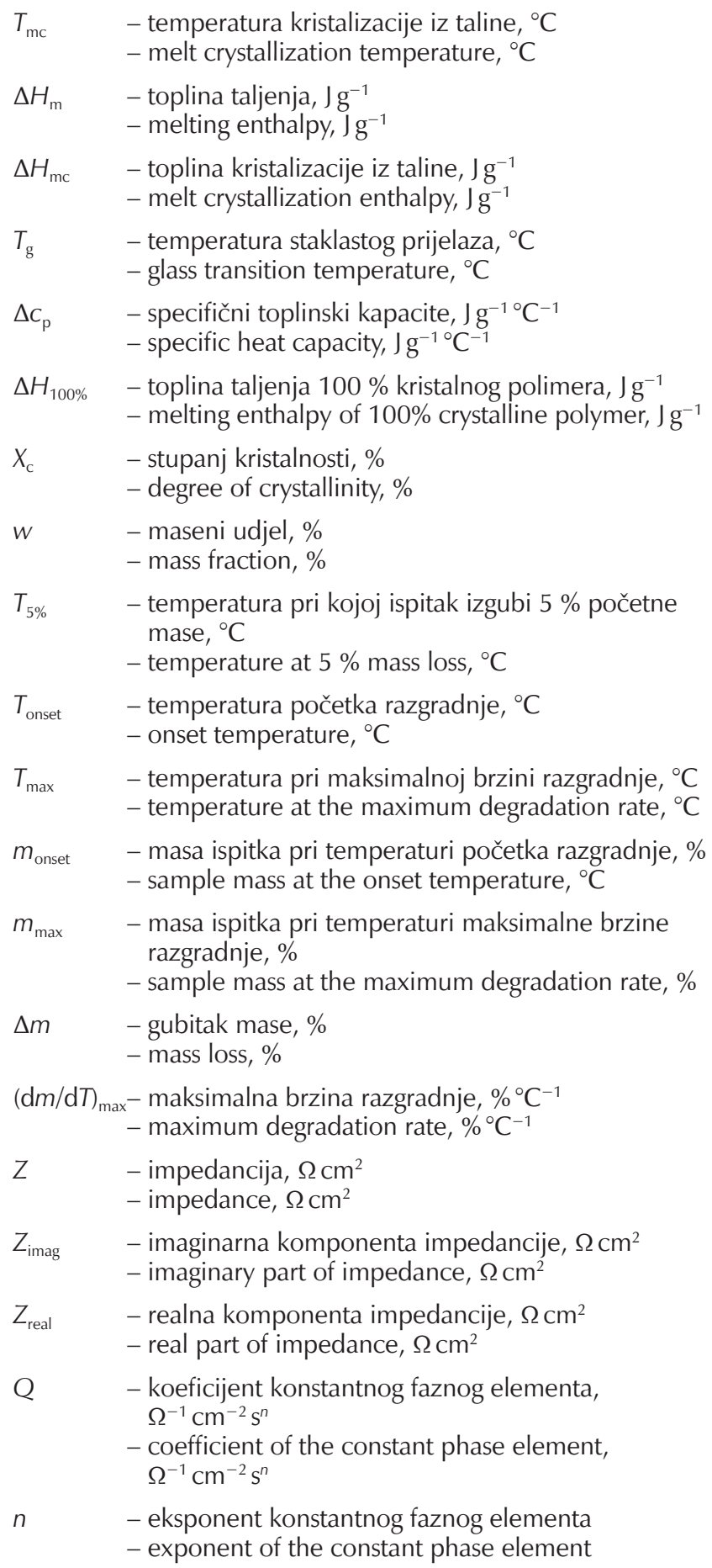

\section{Literatura \\ References}

1. L. Yue, J. Ma, J. Zhang, J. Zhao, S. Dong, Z. Liu, G. Cui, L. Chen, All solid-state polymer electrolytes for high-performance lithium ion batteries, Energy Storage Mater. 5 (2016) 139-164, doi: https://doi.org/10.1016/j.ensm.2016.07.003.

2. A. Arya1, A. L. Sharma, Polymer electrolytes for lithium ion batteries: a critical study, lonics 23 (2017) 497-540, doi: https://doi.org/10.1007/s11581-016-1908-6.

3. P. Dhatarwal, R. J. Sengwa, Influence of solid polymer electrolyte preparation methods on the performance of
(PEO-PMMA)- $\mathrm{LiBF}_{4}$ films for lithium-ion battery applications, Polym. Bull. 75 (2018) 5645-5666, doi: https://doi. org/10.1007/s00289-018-2354-6.

4. J. Gurusiddappa, W. Madhuri, R. Padma Suvarna, K. Priya Dasan, Electrical Properties of PEO-Based Electrolytes, Inter. J. Innov. Sci. Eng. Tech. 4 (2015) 11447-11454, doi: https:// doi.org/10.15680/IJIRSET.2015.0411108.

5. Z. Wen, T. Itoh, Y. Ichikawa, M. Kubo, O. Yamamoto, Blendbased polymer electrolytes of poly(ethylene oxide) and hyperbranched poly[bis(triethylene glycol)benzoate] with terminal acetyl groups, Solid State Ion. 134 (2000) 281-289, doi: https://doi.org/10.1016/S0167-2738(00)00707-4.

6. M. S. Bostan, E. C. Mutlu, H. Kazak, S. S. Keskin, E. T. Oner, M. S. Eroglu, Comprehensive characterization of chitosan/ $\mathrm{PEO} /$ levan ternary blend films, Carbohydr. Polym. 102 (2014) 993-1000, doi: https://doi.org/10.1016/j.carbpol.2013.09.096.

7. G. Patel, M. B. Sureshkumar, P. Patel, Spectroscopic Investigation and Characterizations of PAM/PEO Blends Films, Soft 4 (2015) 9-24, doi: https://doi.org/10.4236/soft.2015.42002.

8. L. Ren, Production of Alginate Beads, Master Thesis, Massey University, Auckland, 2008., str. 2-23.

9. J. P. Soares, J. E. Santos, G. O. Chierice, E. T. G. Cavalheiro, Thermal behavior of alginic acid and its sodium salt, Ecl. Quím. 29 (2004) 53-56, doi: https://doi.org/10.1590/ S0100-46702004000200009.

10. T. Çaykara, S. Demirci, M. S. Eroğlu, O. Güven, Poly(ethylene oxide) and its blends with sodium alginate, Polymer $\mathbf{4 6}$ (2005) 10750-10757, doi: https://doi.org/10.1016/j.polymer.2005.09.041.

11. M. Jakić, Studij međudjelovanja komponenata u polimernim mješavinama poli(vinil-klorid)/poli(etilen-oksid), Doktorska disertacija, Kemijsko-tehnološki fakultet, Split (2014) 37.

12. Z. A. Nur Hanani, Y. H. Roos, J. P. Kerry, Fourier Transform Infrared (FTIR) Spectroscopic Analysis of Biodegradable Gelatin Films Immersed in Water, $\mathrm{u}: 11^{\text {th }}$ International Congress on Engineering and Food. Congress conducted at Athens, Greece, 2011..

13. A. G. Pereira, A. T. Paulino, A. F. Rubira, E. C. Muniz, Polymer-Polymer Miscibility in PEO/Cationic Starch and PEO/ Hydrophobic Starch Blends, EXPRESS Polym. Lett. 4 (2010) 488-499, doi: https://doi.org/10.3144/expresspolymlett.2010.62.

14. R. M. Ramos Wellen, M. Silveira Rabello, I. C. Araujo Júnior, G. J. Macedo Fechine, E. L. Canedo, Melting and crystallization of poly(3-hydroxybutyrate): effect of heating/cooling rates on phase transformation, Polímeros 25 (3) (2015) 296304, doi: https://doi.org/10.1590/0104-1428.1961.

15. M. L. Di Lorenzo, P. Sajkiewicz, P. La Pietra, A. Gradys, Irregularly shaped DSC exotherms in the analysis of polymer crystallization, Polym. Bullet. 57 (2006) 713-721, doi: https:// doi.org/10.1007/s00289-006-0621-4.

16. S. Kuo, Hydrogen-bonding in polymer blends. J. Polym. Res. 15 (2008) 459-486, doi: https://doi.org/10.1007/s10965008-9192-4.

17. J. Yang, X. Wang, G. Zhang, A. Ma, W. Chen, L. Shao, C. Shen, K. Xie, High-Performance Solid Composite Polymer Electrolyte for all Solid-State Lithium Battery Through Facile Microstructure Regulation, Front. Chem. 7 (2019) 1-11, doi: https://doi.org/10.3389/fchem.2019.00388.

18. C. Tonin, A. Aluigi, C. Vineis, A. Varesano, A. Montarsolo, F. Ferrero, Thermal and structural characterization of poly(ethylene-oxide)/keratin blend films, J. Therm. Anal. Calorim. 89 (2007) 601-608, doi: https://doi.org/10.1007/s10973-0067557-7. 
19. F. Zia, M. N. Anjum, M. J. Saif, T. Jamil, K. Malik, S. Anjum, Alginate-Poly(Ethylene) Glycol and Poly(Ethylene) Oxide Blend Materials, u K. M. Zia, M. Zuber and M. Ali (ur.), Algae Based Polymers, Blends, and Composites, Elsevier, Amsterdam, 2017., str. 581-601, doi: https://doi.org/10.1016/B978-012-812360-7.00016-1.
20. K. M. Anilkumar, B. Jinisha, M. Manoj, S. Jayalekshmi, Poly(ethylene oxide) (PEO) - Poly(vinyl pyrrolidone) (PVP) blend polymer based solid electrolyte membranes for developing solid state magnesium ion cells, Eur. Polym. J. 89 (2017) 249-262, doi: https://doi.org/10.1016/j.eurpolymj.2017.02.004.

\section{SUMMARY}

\section{The Influence of Sodium Alginate on the Properties of Polylethylene oxide) as the Matrix for the Preparation of Solid Polymer Electrolyte \\ Sanja Perinović Jozić, Antonija Sesar, Zoran Grubač, and Branka Andričić}

Investigation of the influence of sodium alginate (NaAlg) on the structure and properties of poly(ethylene oxide) (PEO) films cast from aqueous solutions was performed by Fourier transform infrared spectroscopy (FT-IR), differential scanning calorimetry (DSC), non-isothermal thermogravimetry (TG), and electrochemical impedance spectroscopy (EIS). The research aimed to find the optimal blend for the preparation of a solid polymer electrolyte (SPE) film for lithium-ion batteries (LIB). In PEO/NaAlg blend films, hydrogen bonds are formed between PEO and NaAlg, the blends are miscible, and have a lower content of crystalline phase compared to pure PEO film. The films of the blends are more thermally unstable than the film of pure PEO, and show dielectric properties, but the blend $80 \mathrm{PEO} / 20 \mathrm{NaAlg}$ is suitable for the preparation of SPE by addition of lithium salt due to the lowest content of PEO crystalline phase.

\section{Keywords}

Poly(ethylene oxide), sodium alginate, hydrogen bond, crystallinity, thermal stability, impedance

University of Split

Faculty of Chemistry and Technology

Ruđera Boškovića 35

21000 Split, Croatia
Original scientific paper

Received June 12, 2020 Accepted September 3, 2020 